\title{
PAREIASAURIDS FROM THE RIO DO RASTO FORMATION, SOUTHERN BRAZIL: BIOSTRATIGRAPHIC IMPLICATIONS FOR PERMIAN FAUNAS OF THE PARANÁ BASIN
}

\author{
JUAN CARLOS CISNEROS, FERNANDO ABDALA \\ Bernard Price Institute for Palaeontological Research, University of the Witwatersrand, Private Bag 3, WITS 2050, \\ Johannesburg, South Africa.CisnerosJ@science.pg.wits.ac.za, AbdalaF@geosciences.wits.ac.za
}

\author{
MARIA C. MALABARBA
}

Museu de Ciências e Tecnologia, PUCRS, Av. Ipiranga 6651, 90619-900, Porto Alegre, Brazil.mariacm@pucrs.br

\begin{abstract}
Comparison between pareiasaurid materials from Aceguá, originally assigned to Pareiasaurus americanus, and a new cranium from Posto Queimado indicates that they belong to the same taxon. Despite their size difference, the skulls from these localities show similarities in the maxillary dentition and dermal bone ornamentation. Dental and cranial characters confirm the difference between the Brazilian pareiasaurid and the South African Pareiasaurus, supporting the proposed allocation of the Brazilian form in the genus Provelosaurus. The Brazilian pareiasaurid has autapomorphies in the shape of the squamosal and the morphology and placement of the quadratojugal bosses. The presence of the same pareiasaurid in Posto Queimado and Aceguá strongly indicates that these faunas are contemporaneous. The record of dinocephalians and pareiasaurids in Posto Queimado suggests a correlation of the Posto Queimado-Aceguá assemblage with the Guadalupian Tapinocephalus Assemblage Zone of South Africa and Isheevo Assemblage of Eastern Europe. The presence of amphibians tentatively assigned to archegosaurids at Aceguá fauna however, represents a conflict because the last global record of this family is known from the Ocher fauna from Eastern Europe, which is regarded older than the South African Tapinocephalus Assemblage Zone. Finally, the identity of fragmentary remains from the Brazilian Early Triassic assigned to pareiasaurids, is questioned.
\end{abstract}

Key Words: pareiasaurids, Permian, Guadalupian, Lopingian, Rio do Rasto Formation, Brazil

RESUMO - A comparação entre os materiais de pareiassaurídeos provenientes de Aceguá, originalmente atribuídos a Pareiasaurus americanus, e um novo crânio proveniente de Posto Queimado permite reconhecê-los como pertencentes ao mesmo táxon. Apesar da diferença de tamanho, os crânios de ambas as localidades possuem similaridades na dentição e na ornamentação dérmica. Caracteres dentais e cranianos confirmam que o pareiassaurídeo brasileiro difere do gênero sul-africano Pareiasaurus e apoiam a proposta de assignação de $P$. americanus ao gênero Provelosaurus. São propostas autapomorfias para o pareiassaurídeo brasileiro na configuração do esquamosal e na morfologia e posicionamento das bossas quadradojugais. A presença do mesmo táxon em Posto Queimado e Aceguá é uma forte indicação da contemporaneidade destas faunas. O registro de dinocéfalos e pareiassaurídeos em Posto Queimado sugere uma correlação da fauna de Posto Queimado-Aceguá com a Zona de Associação de Tapinocephalus da África do Sul e com a fauna de Isheevo da Europa do Leste, ambas de idade guadalupiana. A presença de anfíbios tentativamente atribuídos a arquegossaurídeos na fauna de Aceguá, contudo, representa um conflito temporal. Isto se deve ao fato de o último registro global desta família encontrar-se na fauna de Ocher, na Europa do Leste, a qual é considerada mais antiga que a Zona de Associação de Tapinocephalus da África do Sul. Finalmente, a identificação de restos fragmentários provenientes do Triássico Inferior brasileiro, atribuídos a pareiassaurídeos, é questionada.

Palavras-chave: pareiassaurídeos, Permiano, Guadalupiano, Lopingiano, Formação Rio do Rasto, Brasil. 


\section{INTRODUCTION}

The Rio do Rasto Formation, in the Paraná Basin, has produced three local faunas containing vertebrates: Aceguá and Posto Queimado, both in the state of Rio Grande do Sul, southern Brazil; and Serra do Cadeado in the state of Paraná. The latter includes the dicynodont Endothiodon (Barberena \& Araújo, 1975), an unnamed Rhinesuchus-like amphibian and the long-snouted amphibian Australerpeton cosgriffi (Barberena, 1998; Barberena \& Dias, 1998; Schoch \& Milner, 2000; Dias \& Schultz, 2003). The Aceguá fauna presents the probable archegosaurid amphibian Bageherpeton longignathus (Dias \& Barberena, 2001), the pareiasaurid Provelosaurus americanus (Araújo, 1985a) and paleoniscoid fishes (Richter, 2000). The recently discovered fauna of Posto Queimado (Figure 1) bears dinocephalians (Langer, 2000), dipnoan and paleoniscoid fishes (Richter \& Langer, 1998), pareiasaurids, temnospondyl amphibians and hybodontiform sharks (Malabarba et al., 2003).

Pareiasaurids and dinocephalians were the earliest tall, massive herbivorous vertebrates in terrestrial ecosystems. The former group shows a wide distribution, with representatives in Scotland, Germany, Russia, China, Niger, South Africa and Brazil (Kuhn, 1969; Araújo, 1984; Sidor et al., 2003), being abundant in the South African Karoo (approximately 11 species from a total of 18; Lee, 1997a). This group was used for correlating Permian faunas of Brazil and South Africa (Barberena et al., 1985a,b) due to the alleged presence of Pareiasaurus in these regions. In addition, the phylogenetic significance of pareiasaurids achieved attention recently when the old hypothesis of its close relationship to turtles (Gregory, 1946) gained support in a cladistic framework (Lee, 1997a, b; but see Laurin \& Reisz, 1995; deBraga \& Rieppel, 1997 and Rieppel \& Reisz, 1999).

The first record of pareiasaurids in South America included three individuals, collected in two small outcrops located at $58 \mathrm{~km}$ and $58.6 \mathrm{~km}$ from the city of Bagé along the Bagé-Aceguá Highway (BR 153), in the municipality of

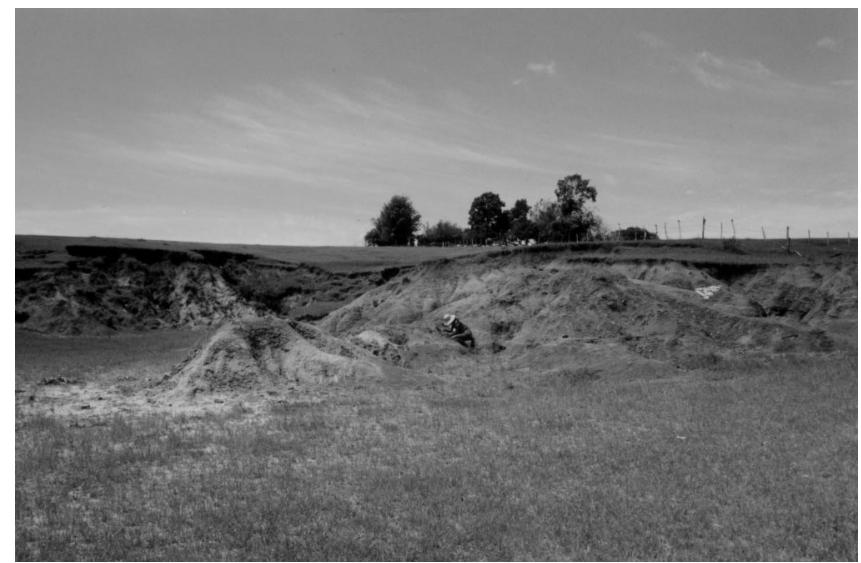

Figure 1. Ravines (locally known as "sangas") at Posto Queimado. Sediments cropping out at this locality were briefly described by Langer (2000).
Aceguá, state of Rio Grande do Sul, southern Brazil. These specimens were originally ascribed to the South African genus Pareiasaurus and placed in the new species $P$. americanus by Araújo (1985a,b). This author published several reports describing the cranial and postcranial anatomy of the mentioned species (Araújo, 1985a,b, 1986a,b; Araújo-Barberena, 1987, 1989a,b). Subsequently, Lee (1997a,b) questioned the assignment of the Brazilian species to Pareiasaurus, and transferred it to the new genus, Provelosaurus, providing an amended diagnosis for the taxon. This consisted of a "unique combination of primitive and derived features" with no autapomorphies (Lee, 1997a). In addition, a close interrelationship between this taxon, the South African dwarf-pareiasaurids (Anthodon, Nanoparia and Pumiliopareia) and turtles was proposed (Lee, 1997a, b).

In this contribution we describe a pareiasaurid specimen (Figures 2 and 3 ) recently reported from the locality of Posto Queimado (Malabarba et al., 2003). The associated humerus previously referred to this pareiasaurid is here regarded as belonging to an aquatic amphibian. The new specimen from Posto Queimado is compared with the pareiasaurids from Aceguá and assigned to Provelosaurus. In addition, a revised diagnosis for the Brazilian taxon is provided. Biostratigraphic implications on the basis of the composition of each tetrapod assemblage of the Rio do Rasto Formation are addressed, and the identity of presumed pareiasaurid remains recently reported from the Lower Triassic Sanga do Cabral Formation (Schultz \& Dias-da-Silva, 1999; Lucas, 2002), is also evaluated. Institutional abbreviations. AM, Albany Museum, Grahamstown; BMNH, The Natural History Museum, London; BP, Bernard Price Institute for Palaeontological Research, University of the Witwatersrand, Johannesburg; MCP, Museu de Ciências e Tecnologia, Pontificia Universidade Católica do Rio Grande do Sul, Porto Alegre; SAM, South African Museum, Cape Town; TM, Transvaal Museum, Pretoria; UFRGS, Universidade Federal do Rio Grande do Sul, Porto Alegre; UMZC, University Museum of Zoology, Cambridge.

\section{SYSTEMATIC PALAEONTOLOGY}

\author{
REPTILIA Laurenti, 1768 \\ PARAREPTILIA Olson, 1947 \\ (sensu deBraga \& Reisz, 1996) \\ PAREIASAURIDAE Seeley, 1888
}

\section{Provelosaurus americanus (Araújo, 1985)}

Referred material. MCP 4263PV, left partial cranium including portion of the snout with maxillary teeth, orbit, most of the temporal region and the quadrate (Figures 2 and 3).

Horizon and locality. Morro Pelado Member, Rio do Rasto Formation, Guadalupian. Locality of Posto Queimado $\left(30^{\circ} 01^{\prime}\right.$ S, 54 $09^{\prime} \mathrm{W}$ ), São Gabriel Municipality (Malabarba et al., 2003). 

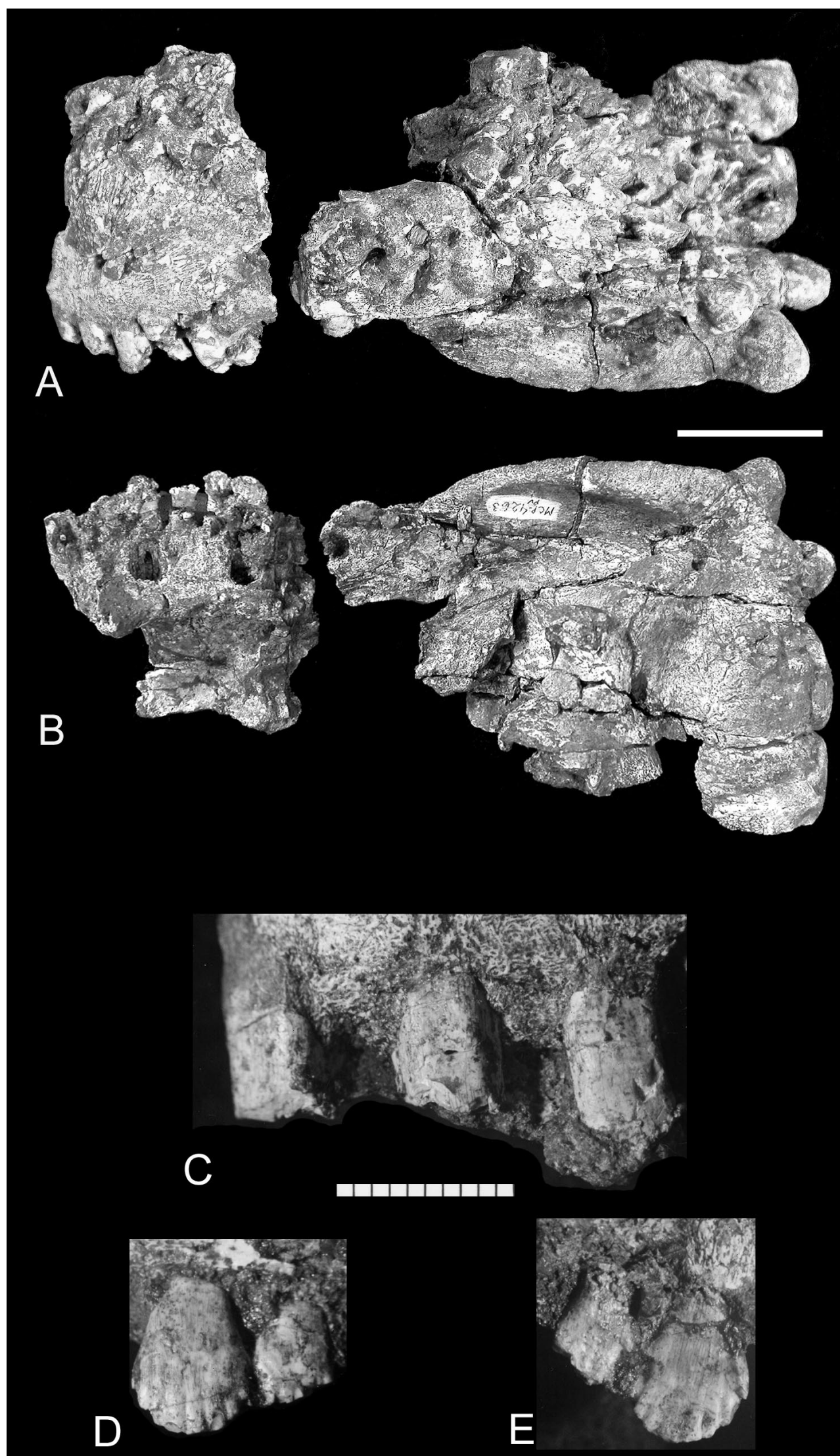

Figure 2. Provelosaurus americanus MCP 4263PV partial cranium. A, lateral view; B, medial view; C, first, second and third maxillary teeth in lateral view; D, E, ninth and tenth teeth in lateral view and medial view. Scale bar is $3 \mathrm{~cm}$ for $A$ and $B$, and $1 \mathrm{~cm}$ for $C-E$ 


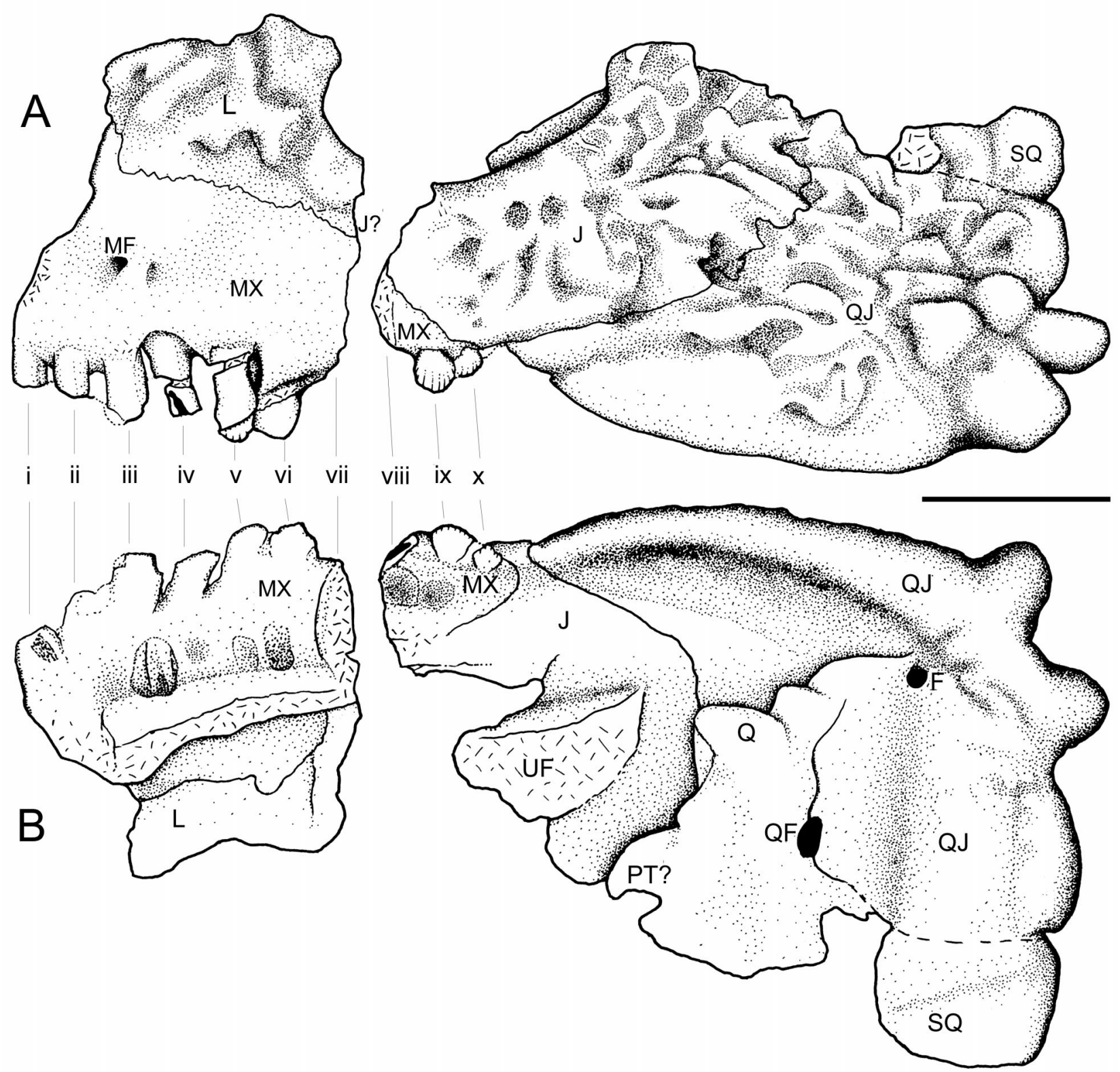

Figure 3. Provelosaurus americanus, MCP 4263PV partial cranium. A, lateral view, slightly rotated outwards to show marginal dentition. B, medial view. Abbreviations: F, unnamed foramen; J, jugal; MX, maxillar; L, lacrimal; MF, maxillary foramen; Q, quadrate; QF, quadrate foramen; QJ, quadrato-jugal; SQ, squamosal; UF, unidentified fragment of bone. Roman numbers indicate maxillary teeth. Scale bar $=3 \mathrm{~cm}$.

Diagnosis. Pareiasaurid characterized by the following autapomorphies: quadratojugal with a long smooth ventrolateral surface with two prominent cylindrical bosses located distally; and squamosal dorsoventrally expanded.

Remarks on diagnosis. This study refers to the cranium and dentition of the Brazilian pareiasaurid, and the diagnosis presented here is, in consequence, limited to cranial features. This allows the discussion of the previous diagnosis of Provelosaurus (Araújo, 1985a), which was also restricted to cranial characters. Further study of the skeleton of
Provelosaurus may demonstrate additional diagnostic characters. The morphology of the anterior maxillary teeth of Provelosaurus seems to differentiate this taxon from the remaining Gondwanan pareiasaurids (see discussion below), but this character is also present in Laurasian forms.

\section{Examined Material}

Holotypes. Pareiasaurus americanus Araújo 1985, UFRGS 0231P, cranium lacking lower jaw (Figure 4), scapulocoracoid and humerus. Anthodon serrarius Owen 1876, BMNH R47337, 

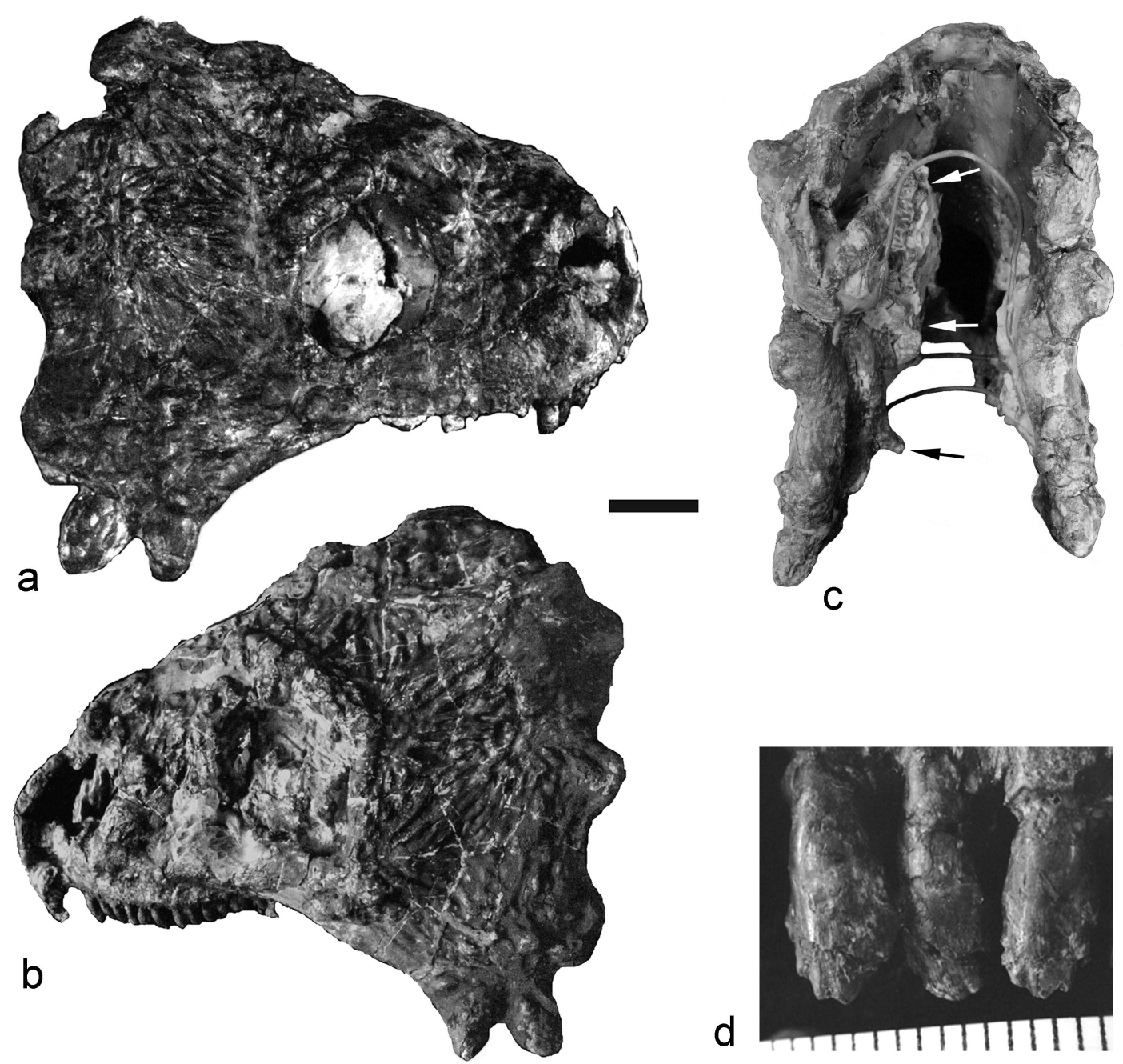

Figure 4. Provelosaurus americanus, cranium of the holotype UFRGS PV0231P. A, right lateral view; B, left lateral view; C, occipital view, indicating lateral compression at the braincase; $\mathbf{D}$, first, second and third left maxillary teeth.

partial cranium and lower jaw. Pareiasaurus bombidens Owen 1876, BMNH R1714, partial snout and mandible in occlusion. Pareiasaurus serridens Owen 1876, BMNH R4063, cast of the cranium and original lower jaw, vertebrae, scapula and osteoderms. Nanoparia pricei Broom and Robinson 1948, BP/1/6, cranium and articulated postcranial remains, including presacral vertebrae and ribs, shoulder girdle and osteoderms. Sclerosaurus armatus Meyer 1859, AM 2481, cranium; AM 2482, complete skeleton in ventral view; AM 2483, complete skeleton in dorsal view. Casts of the holotype housed at Naturhistorisches Museum, Basel.

Pareiasaurus americanus Araújo 1985, UFRGS PV0232P (hypodigm) small pelvic girdle; UFRGS PV0233P (paratype) partially articulated postcranium, including humerus, vertebrae, ribs, pelvis, femur, tibia, fibula and osteoderms.

Non-type material. Bradysaurus seeleyi Haughton and Boonstra 1929, SAM PK5624.

Deltavjatia vjatkensis (Hartmann-Weinberg 1937), UMZC T1321.
Elginia mirabilis Newton 1893, BMNH R2114, cast of the cranium without lower jaw.

Pareiasaurus serridens Owen 1876, TM 1474, complete cranium.

Anthodon serrarius Owen 1876, BP/1/548, cranium and postcranium.

Pareiasuchus nasicornis Haughton \& Boonstra 1929, BP/1/3653, cranium.

Scutosaurus karpinskyi (Amalitsky 1922), BMNH R4029, cast of the cranium, and many postcranial bones.

\section{DESCRIPTION}

\section{Cranium}

The new specimen (MCP 4263-PV; Figure 2) is mostly well preserved, without major distortions, and is represented by two fragments of the left side of the skull, including the quadrate. The preserved cranial length is $172 \mathrm{~mm}$, and the 
estimated total length (from the posterior boss of the squamosal to the tip of the snout) would be $190 \mathrm{~mm}$. The facial portion of the cranium is represented by the maxilla bearing ten marginal teeth (two of them represented by broken roots), the lacrimal, and small portions of the jugal and prefrontal. Both the posterior margin of the external naris and the anteroventral margin of the orbit are outlined. The quadratojugal, an almost entire jugal, ventral portion of the squamosal and postorbital, and medially, the quadrate, are also present.

The external surface of the maxilla lacks major ornamentation. The maxilla is slightly convex, and its anterodorsal end contributes to the posterior border of the external naris. The premaxilla/maxilla contact is not preserved, and the missing anteriormost end of the maxilla might have borne an additional marginal tooth. The only clear suture in the snout is the contact between maxilla and lacrimal. The anterior dorsal extension of the maxilla is weak, not exceeding the middle level of the orbit height. Part of the maxillary contribution to the palate is also preserved, including several rounded pits at the base of the teeth.

A web of pits and bosses ornaments the temporal region where the contact of the jugal with the quadratojugal is the only visible suture. The ventral border of the quadratojugal is slightly convex, without ornamentation. There are two subequal major cylindrical bosses in the distal part of the quadratojugal, and two less prominent but wider ones on the posterior border of the temporal region (Figures 2 and 3). These four bosses are located close to each other, and the dorsalmost is that located at the ventral portion of the squamosal. The posteromedial region of the quadratojugal and squamosal constitutes a continuous and smooth surface. However, small ventromedially directed projections are present on the quadratojugal. In medial view it is possible to distinguish the contact between the quadratojugal and the squamosal which ends in the quadrate foramen. From this foramen, the suture between quadratojugal and quadrate projects laterally. A second smaller foramen is located in the lateral edge of the quadrate and is limited posteriorly by the quadratojugal (Figure 3B). We found no reference to this foramen in the literature. This negative evidence may be caused by insufficient preparation in studied specimens and poor illustration in the literature. The massive quadrate is anteromedially directed and a portion of the pterygoid is probably attached anterodorsally, but the suture between these elements is not clear.

\section{Dentition}

Six partial and two complete crowns are preserved in MCP 4263PV (Figures 2 and 3). In addition, roots of two more teeth can be seen in the broken margins of the separated cranial portions. The missing anteriormost portion of the maxilla might have carried an additional tooth, in which case the total maxillary tooth count would be 11 . The total number of marginal teeth in the upper jaw, including premaxillary elements, would be 12 to 13 . They are mesodistally flattened and serrated. The last maxillary teeth are medially inclined, whereas the anteriormost teeth are more vertically positioned. The most anterior elements are not completely preserved, but their bases are remarkably more elongated than in the posterior teeth. The fourth preserved tooth emerges through a concave margin that delimits its alveolus. The ninth tooth has the only fully preserved crown, featuring nine cusps (Figure $2 \mathrm{~d}, \mathrm{e}$ ). The crown is semicircular, slightly convex labially, flattened lingually, and its anteroposterior length is approximately $80 \%$ of the height of the tooth. A large interdental space, of nearly the size of the neck of the tooth, is present between adjacent anterior teeth. The rounded openings in the medial surface of the maxilla, close to the base of the third, fifth and sixth teeth, are interpreted as resorption pits. These are larger in the third and sixth elements, and the root of the third tooth is visible through the opening.

A longitudinal section of a fragment of the fourth maxillary tooth was prepared (Figure 5), in order to explore the enamel ultrastructure. The enamel layer is thin, measuring about $50 \mu \mathrm{m}$, and has a simple structure. It is mostly made up of parallel crystallites dominated by incremental lines. These lines increase in thickness towards the outer enamel surface. Close to the enamel-dentine junction there is a thin layer (approx. $10 \mu \mathrm{m}$ ) in which the incremental lines cannot be discerned. We interpret this as the basal unit layer. The enamel pattern in Provelosaurus is fairly similar to that in an unidentified pareiasaurid tooth from the South African Tapinocephalus Assemblage Zone (Sander, 1999). In

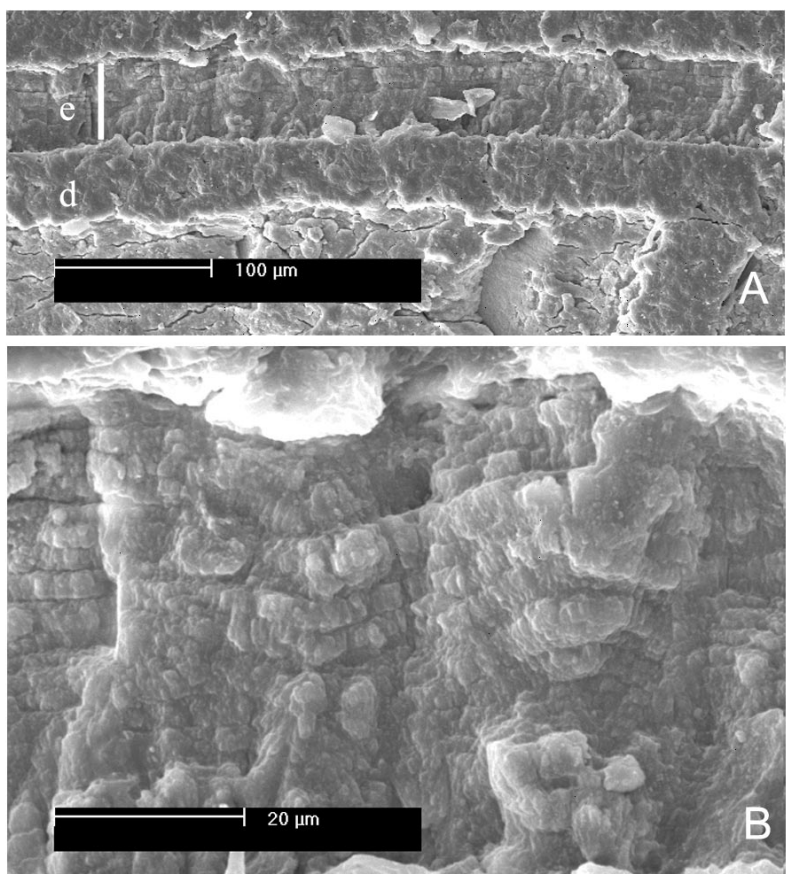

Figure 5. A, longitudinal section on a fragment of the fourth maxillary tooth of Provelosaurus americanus MCP 4263PV; B, detail of enamel, showing incremental lines and basal unit layer. Abbreviations: d, dentine; e, enamel. 
both cases, the structure is fairly simple, with incremental lines and a thin basal unit layer. In the pareiasaurid from the Tapinocephalus Assemblage Zone, however, these incremental lines increase slightly in thickness $(2 \mu \mathrm{m}-3 \mu \mathrm{m})$ towards the inner region and the enamel is considerably thicker $(100 \mu \mathrm{m}$ $-200 \mu \mathrm{m}$; Sander, 1999).

\section{DISCUSSION}

The original description of Provelosaurus americanus was based on three specimens collected in outcrops of the Rio do Rasto Formation in Aceguá (Araújo, 1985a,b, 1986a,b; Araújo-Barberena, 1987, 1989a,b). The holotype UFRGS PV0231P (Figure 4) and the paratype UFRGS PV0232P come from an outcrop located at $58 \mathrm{~km}$ from the city of Bagé (tentatively $31^{\circ} 50^{\prime} 20^{\prime \prime} \mathrm{S}, 54^{\circ} 09^{\prime} 54^{\prime \prime} \mathrm{W}$ ), along the Bagé-Aceguá Highway (National Road BR 153; Araújo, 1985a), Aceguá Municipality. The paratype UFRGS PV0233P was collected in an outcrop located at $58.6 \mathrm{~km}$ from Bagé along the same highway (Araújo, 1985a).

The pareiasaurid cranium from Posto Queimado exhibits notable similarities with UFRGS PV0231P: (i) anterior marginal teeth with elongated crown bases and wide interdental spaces; (ii) a smooth ventral margin of the quadratojugal; and (iii) presence of two sub-equal major cylindrical bosses in the distal margin of the quadratojugal (see Figures 2, 3 and 4). In addition, the ventrolateral surface of the maxilla of both skulls lacks ornamentation, and their temporal regions show well- differentiated pits and bosses. The most significant differences between the two skulls are their size (MCP 4263PV is approximately 40\% smaller than UFRGS PV0231P) and the location of the two wide and less prominent bosses on the posteroventral border of the temporal region. These bosses are contiguous in MCP 4263PV, but separated by a concavity in the cranium from Aceguá. In addition, the latter exhibits a protrusion on the anterior surface of the maxilla posterior to the nostril, which is absent in MCP 4263PV. This swelling is clear on the left side of UFRGS PV0231P, but less evident on the right maxilla, due to diagenesis. Considering the strong similarities mentioned above, we interpret the size differences as linked to ontogeny, and the distribution of the bosses on the posterior border of the skull and the development of the maxillary protuberance could also be the result of ontogenetic and/or individual variation.

\section{On the diagnosis of the Brazilian pareiasaurid}

Araújo (1985a) distinguished Pareiasaurus americanus from the South African $P$. serridens by: (i) a single boss anterior to the one located in the posteroventral angle of the cranium; (ii) a wider angle between the rostrum and the orbital/postorbital areas in the ventral margin of the cranium; (iii) parietal/postorbital suture placed at a lower level than frontal/prefrontal/"postorbital" (that author possibly refers to the postfrontal, "postorbital" as stated in the original diagnosis is probably a lapsus memoriae), producing a larger visible area of the parietal in lateral view; (iv) prefrontal, postfrontal and postorbital of different sizes; (v) larger anteroposterior extension of the jugal; (vi) postorbital and squamosal remarkably large; (vii) quadratojugal smaller than squamosal; (viii) pterygoid process rising immediately above the medial condyle of the quadrate; and (ix) distinct shape of the posttemporal fenestra.

Among the above mentioned characters, "i" seems to be the most reliable diagnostic feature for the Brazilian taxon. The ventral margin of the quadratojugal anterior to the posteroventral bosses is smooth and more extended than in other pareiasaurids. Considering the angle between the rostrum and the lateral flange (character ii), the values for the Brazilian species are approximately $145^{\circ}$ in UFRGS PV0231P and $150^{\circ}$ in MCP $4263 \mathrm{PV}$, but a similar value is found in Elginia, and wider angles occur in Bradysaurus baini and Deltavjatia (Lee, 1997a, fig. 6). Examination of the figure of P. americanus in Araújo (1985b, fig. 1) shows that the sutures between parietal/postorbital and prefrontal/ frontal/postfrontal (character iii) seem to be at the same level. In addition, the apparent larger area of the parietal, visible in lateral view, is explained by the extreme degree of compression in UFRGS PV0231P. Considering the relative sizes of the prefrontal, postfrontal and postorbital (character iv), it is clear that in almost all pareiasaurids the last element is always the largest, while the postfrontal appears to be the smallest (Boonstra, 1932, plates 1 and 2; Lee, 1997b, fig. 4 and 6; and pers. obs.). The anteroposterior extension of the jugal (character $v$ ) does not seem to differ from that present in most pareiasaurids (Boonstra, 1932, plate 1; Lee, 1997b, fig. 6; and pers. obs.). Regarding the sizes of the postorbital and squamosal (character vi), the first element is not distinctively larger than in other taxa, while the squamosal appears to be remarkably larger dorsoventrally, remaining diagnostic. The next character, quadratojugal smaller than squamosal, is a relative measurement linked to the size of the squamosal, and may represent a repetition of character "vi" (i. e., large size of the squamosal). The last two characters (viii, ix) are the result of the strong lateral compression, noteworthy in the occipital view, that pushed the paroccipital process, occipital bones, and the quadrate towards the left internal surface of the dermal cranium (Figure 4C). In another form of statement of character "ix" (distinct shape of the posttemporal fenestra), Lee (1997a, p. 278) considers the "paroccipital process straight in posterior view, upturned distally" as a valid feature for P. americanus. The deformation bias mentioned above, however, prevents safe assertions about morphology and placement of most of the basicranial bones.

Lee (1997a) transferred Pareiasaurus americanus to a new genus, Provelosaurus, arguing that it was not closely related to the South African Pareiasaurus serridens. No exclusive characters for the Brazilian species were provided and the diagnosis of this taxon was based in a "unique 


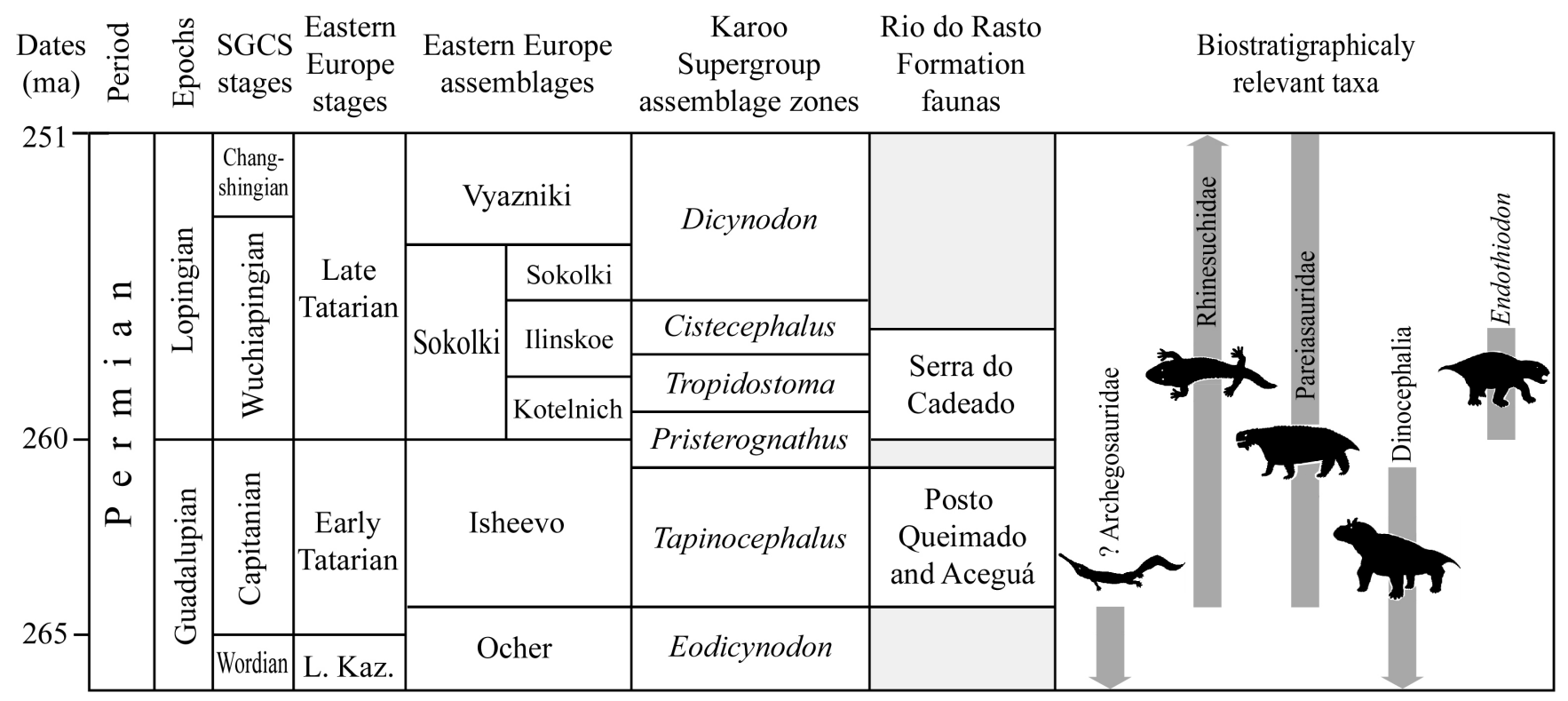

Figure 6. Correlation of the Rio do Rasto faunas with Karoo Supergroup assemblage zones (South Africa) and Eastern Europe assemblages. Based on this work, Rubidge (1995), Golubev (2000) and Gradstein \& Ogg (2004). SGCS, Standard Global Chronostratigraphic Scale.

combination of primitive and derived features" (Lee, 1997a, p. 277). Here, we recognize two diagnostic characters for Provelosaurus americanus. Considering our first diagnostic character (quadratojugal with a long smooth ventrolateral surface possessing two prominent cylindrical bosses located distally), a quadratojugal with a long and smooth ventrolateral surface is also observed in Deltavjatia and Elginia, but these taxa lack two distal cylindrical bosses. On the other hand, the quadratojugal of Pumiliopareia pricei is quite similar to that of $P$. americanus concerning the two distally located bosses, but shows additional smaller bosses located on the ventrolateral surface of this bone. The second character, squamosal dorsoventrally expanded, is clearly distinctive from the remaining pareiasaurids, in which this bone is either subquadrate or antero-posteriorly enlarged.

Another putative diagnostic character for the Brazilian taxon is the presence of anterior maxillary teeth with thin crown bases, and a generally wide interdental space that comprises at least $50 \%$ of the base width. However, most teeth in the European pareiasaurids (i.e., Elginia, Deltavjatia, Scutosaurus) posses thin crown bases. The anterior upper teeth in BM R1714, a South African pareiasaurid originally described by Owen (1876) as Pareiasaurus bombidens, and considered pareiasaurid indet. by Lee (1997a), also feature thin crown bases. In addition, the lower teeth of Shansisaurus, a Chinese pareiasaurid, feature elongated and thin tooth bases (Gao, 1983, plate 1, fig. 1 and 2). Among these taxa, only Scutosaurus seems to possess interdental spaces between the anterior maxillary teeth as wide as in the Brazilian species.
Therefore, this character allows for the differentiation of Provelosaurus from the remaining Gondwanan forms.

\section{Dental replacement}

The new specimen of Provelosaurus americanus exhibits resorption pits on the lingual surface of the maxilla, at the base of all the preserved teeth, with the exception of the recently erupted last one. The concave ventral margin of the maxilla, around the fourth tooth, indicates that this is not fully erupted and not anchored in its alveolus. Resorption pits have been documented in the lower jaw of the South African Pareiasaurus 'bombidens' BM R1970 (Owen, 1876, plate 8; also quoted in Edmund, 1960), and in the Chinese Shansisaurus (Gao, 1983, text fig. 1; plate 1, fig. 1). Marginal teeth in eruption are also known in the premaxilla of the South African specimen BP/1/4105 of Pareiasuchus peringueyi and in the lower jaw of the Zambian specimen BP/1/3656 of Pareiasuchus nasicornis (Lee et al., 1997), in the latter case without resorption pits. Replacement pits in the maxilla of pareiasaurids, however, have not been previously documented, but are present, with different degrees of development, in practically the entire marginal dentition of the cranium and lower jaw of Bradysaurus seeleyi (SAM-PK 5624).

The presence of resorption pits in bone and teeth roots during dental replacement is known in a number of reptilian lineages (Edmund, 1960). Even though numerous specimens represent pareiasaurids across Pangaea, their pattern of tooth replacement is poorly documented in the 
literature. The mention of alternate replacement by Edmund (1969) in Pareiasaurus 'bombidens' remains the only reference of this phenomenon in the group. Sizes of the resorption pits have been shown to be proportional to the size of the replacement tooth at least in pleurodont reptiles, in which the nature of the replacement makes more prominent the pits at the base of the old tooth (Edmund, 1969). The different sizes of the resorption pits at the base of successive teeth in the new specimen of Provelosaurus americanus seems to indicate that alternate replacement was also present in the Brazilian species. Recent studies have shown that this kind of tooth replacement also occurs in other members of the Parareptilia, such as leptopleuronine procolophonids, in which resorption pits in the lower jaw have also been documented (Small, 1997; Sues et al., 2000).

\section{Biostratigraphic implications}

Based on the discovery of dinocephalians at Posto Queimado, Langer (2000) correlated this Brazilian fauna with the Eodicynodon and Tapinocephalus Assemblage Zones (AZ) of South Africa. In addition, the author proposed a younger age for the Aceguá fauna based on the sister group relationship of the Brazilian pareiasaurid with the South African "dwarf-pareiasaurs" as proposed by Lee (1997a). The subsequent discovery of Provelosaurus americanus at Posto Queimado allowed for direct correlation with Aceguá (Malabarba et al., 2003). This pareiasaurid is, thus far, the only element in common to the Aceguá and Posto Queimado faunas. The presence of pareiasaurids in conjunction with dinocephalians at Posto Queimado was used by Malabarba et al. (2003) to correlate these Brazilian faunas with the Tapinocephalus AZ of South Africa, the only known global fauna in which these groups are recorded together.

The occurrence of an archegosaurid amphibian at Aceguá (Dias \& Barberena, 2001) is in conflict with this correlation, since the stratigraphically youngest record of these temnospondyls is from the Ocher Assemblage of Eastern Europe (base of the Early Tatarian; Golubev, 2000). This unit is considered older than the Isheevo Assemblage (Golubev, 2000) with which the Tapinocephalus AZ of South Africa has been correlated (Smith \& Keyser, 1995a; see Figure 6). On the other hand, the oldest record of pareiasaurids is from the Tapinocephalus AZ (Lee, 1997a). The coexistence of archegosaurids and pareiasaurids at Aceguá imply either the youngest record for the Archegosauridae, or the oldest for the Pareiasauridae. Because the specimens of Bageherpeton and Provelosaurus were collected at different exposures, it is possible that they do not belong to the same horizon, although we do not have precise stratigraphic data to assess this hypothesis. We should also mention that the taxonomic assignment of Bageherpeton longignathus to the Archegosauridae is not definitive (Dias \& Barberena, 2001). Even with this uncertainty, these authors provisionally allocated B. longignathus within the Platyoposaurinae clade, which comprises the latest members of the Archegosauridae. All the platyoposaurines are known from the Kazanian to the base of the Early Tatarian of eastern Europe (Schoch \& Milner, 2000; Golubev, 2000). If $B$. longignathus was an archegosaurid, it could represent the youngest member of the Archegosauridae, extending only slightly the temporal record of the group. Considering the stratigraphic and taxonomic uncertainty of $B$. longignathus, and the phylogenetic relationships of Provelosaurus sensu Lee (1997a,b), we regard the correlation of the Posto Queimado/Aceguá fauna with the Tapinocephalus/ Isheevo Assemblages as more plausible (Figure 6).

Provelosaurus forms a monophyletic group with the "dwarf-pareiasaurs" Anthodon, Nanoparia and Pumiliopareia, and chelonians (Lee, 1997a,b). The aforementioned South African pareiasaurids are restricted to the Lopingian (Cistecephalus and Dicynodon AZ; Lee 1997a), whereas the earliest record of turtles is in the Late Triassic (Rougier et al., 1995). On the contrary, the Guadalupian South African pareiasaurids from the Tapinocephalus AZ (Bradysaurus, Embrithosaurus, Nochelesaurus) have a basal position among pareiasaurids, and are not closely related to Provelosaurus. The biostratigraphic correlation proposed here for the Brazilian faunas with Provelosaurus implies an earlier origin (minimally Guadalupian) for the monophyletic group including dwarf-pareiasaurids and chelonians (Lee, 1997a,b).

The Serra do Cadeado local fauna consists of the dicynodont Endothiodon (Barberena \& Araújo, 1975; Barberena et al., 1985a,b) and two temnospondyl amphibians: an unnamed rhinesuchoid (Barberena \& Dias, 1998) and Australerpeton cosgriffi. The taxonomic placement of both forms is disputed between the Rhinesuchidae and Archegosauridae (Schoch \& Milner, 2000; Dias \& Schultz, 2003). The combined presence of Endothiodon and archegosaurids is anomalous, as the former is restricted to the upper levels of the Pristerognathus AZ, the Tropidostoma AZ and the lower part of the Cistecephalus AZ in South Africa. These faunal assemblages are considered younger than the Ocher Assemblage of eastern Europe (Smith \& Keyser, 1995b,c,d) where the last archegosaurids have been recorded. The identity of Australerpeton as a rhinesuchid, on the other hand, fits better the biostratigraphic data, given that rhinesuchids and Endothiodon coexisted in the Karoo Basin (Rubidge et al., 1995). Consequently, the Serra do Cadeado fauna can be loosely correlated with Pristerognathus, Tropidostoma and Cistecephalus AZs (Figure 6).

The fossil record of pareiasaurids is widely believed to be restricted to the Guadalupian-Lopingian (Boonstra, 1932; Araújo, 1984; Barberena et al., 1985a; Laurin \& Reisz, 1995; Lee, 1997a). However, pareiasaurid-like material has recently been reported in the Early Triassic Sanga do Cabral Formation, in Rio Grande do Sul State, Brazil (Schultz \& Dias-da-Silva, 1999; Lucas, 2002). This record is based on 


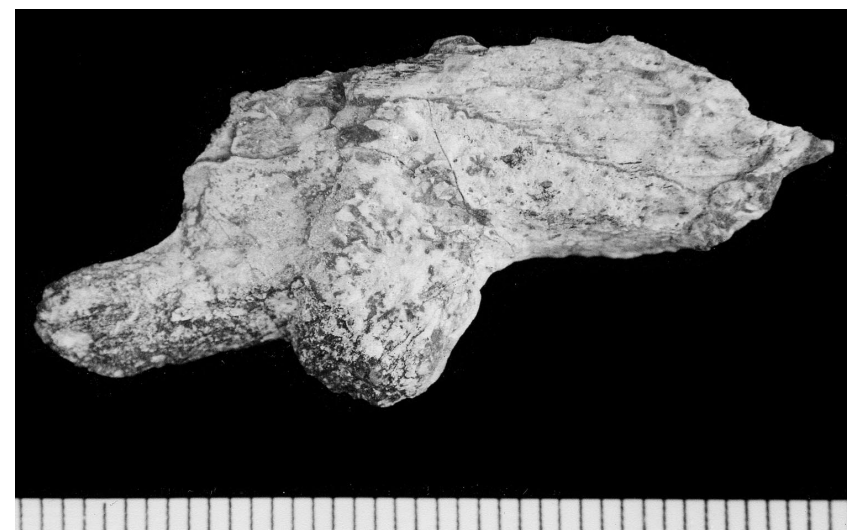

Figure 7. Cranial fragment in (?) internal view, of the supposed pareiasaurid from the Lower Triassic Sanga do Cabral Formation. Scale in millimetres.

two non-associated fragments, interpreted as an ulnar olecranon process and a fragment of the posteroventral margin of the cranium, including part of the quadratojugal with the two distal bosses. The first specimen has been recently re-identified as a posterior portion of an amphibian lower jaw (Cesar Schultz, pers. comm.). The second fragment (Figure 7) depicts sutures that allow the recognition of at least three different bones, being clearly a skull fragment. However, the presence of these sutures contrast with its interpretation as a posteroventral margin of a pareiasaurid cranium, which is only formed by the quadratojugal. In addition, the two protuberances identified as quadratojugal bosses (Schultz \& Dias-da-Silva, 1999) do not match with the morphology of the bosses in the two known craniums of Provelosaurus americanus or any other pareiasaurid. At this stage, it is not possible to provide a reliable taxonomic identification for this fragmentary material.

Lucas (2002, p. 138) also extended the pareiasaurid record into the Triassic based on the poorly known specimen of Sclerosaurus armatus. Lee $(1995,1997 \mathrm{a}, \mathrm{b})$ proposed this enigmatic species as the sister taxon to the Pareiasauria, being the only Triassic taxon, besides chelonians, included in his Pareiasauroidea. DeBraga (2003) considered the holotype and only specimen of Sclerosaurus to be a leptopleuronine procolophonid, conclusion also endorsed by JCC after observation of a cast of the specimen. This evidence altogether does not seem to provide a real basis yet to suggest the temporal extension of non-chelonian pareiasaurids or pareiasauroids (sensu Lee, 1995, 1997a,b) into the Triassic.

\section{ACKNOWLEDGMENTS}

We thank to C. Schultz (UFRGS), M. Raath and B. Rubidge (BP), S. Kaal and R. Smith (Iziko Museums; SAM), H. Fourie (TM), B. de Klerk (AM), R. Symonds and J. Clack (UMZC), and S. Chapman (BMNH) for access to specimens under their care. Thanks are due to M. C. Langer, M. A. Raath, R. R. Reisz and B. S. Rubidge for comments on the manuscript, and E.V. Dias for discussion on Permian biostratigraphy. We specially recognize the help and kindness of the Modesto family, owners of the property at Posto Queimado were the field work was done. Financial support was provided by the Pontifícia Universidade Católica de Rio Grande do Sul and the University of the Witwatersrand Research Council through Postdoctoral Research Fellowships bestowed on FA; and PAST (Palaeo-Anthropological Scientific Trust, Johannesburg) through a study grant provided to JCC. The Royal Society and PAST provided grants that made possible a research visit (FA) to palaeontological collections in the United Kingdom.

\section{REFERENCES}

Amalitzky, V. 1922. Diagnoses of the new forms of vertebrates and plants from the Upper Permian of North Dvina. Bulletin de l'Académie des Sciences de Russie, 16:1-12.

Araújo, D.C.F. 1984. Sistemática e taxonomia dos pareiassauros: histórico e perspectivas atuais. Pesquisas, 16:227-249.

Araújo, D.C.F. 1985a. Sobre Pareiasaurus americanus sp. nov., do Permiano Superior do Rio Grande do Sul, Brasil. I- Diagnose específica. Anais da Academia Brasileira de Ciências, 57:63-66.

Araújo, D.C.F. 1985b. Estudo do material sul-americano de Pareiasauroidea: II - Descrição osteológica de crânio de Pareiasaurus americanus. Anais da Academia Brasileira de Ciências, 57:67-85.

Araújo, D.C.F. 1986a. Estudo do material sul-americano de Pareiasauroidea: III - Descrição osteológica da escápula-coracóide de Pareiasaurus americanus. Anais da Academia Brasileira de Ciências, 58:381-387.

Araújo, D.C.F. 1986b. Estudo do material sul-americano de Pareiasauroidea: IV - Descrição osteológica do propódio e epipódio dos membros anterior e posterior de Pareiasaurus americanus. Anais da Academia Brasileira de Ciências, 58:389-403.

Araújo-Barberena, D.C. 1987. Armadura osteodérmica de Pareiasaurus americanus Araújo 1985 (Cotylosauria, Procolophonia, Pareiasauroidea) do Permiano Superior do Rio Grande do Sul. Paula-Coutiana, 1:11-16.

Araújo-Barberena, D.C. 1989a. Estudo do material sul-americano de Pareiasauroidea: V- Descrição da pélvis de Pareiasaurus americanus Araújo 1985. Anais da Academia Brasileira de Ciências, 61:285-294.

Araújo-Barberena, D.C. 1989b. Estudo do material sul-americano de Pareiasauroidea: V - Descrição do esqueleto axial de Pareiasaurus americanus Araújo 1985. Anais da Academia Brasileira de Ciências, 61:295-309.

Barberena, M.C. 1998. Australerpeton cosgriffi n. g., n. sp., a Late Permian rhinesuchoid amphibian from Brazil. Anais da Academia Brasileira de Ciências, 70:125-137.

Barberena, M.C. \& Araujo, D.C. 1975. Tetrápodos fósiles de Sudamérica y deriva continental. Congreso Argentino de Paleontología y Bioestratigrafía, 1, Tucumán. Actas, 1:497-504. 
Barberena, M.C.; Araújo, D.C. \& Lavina, E.L. 1985a. Late Permian and Triassic tetrapods of Southern Brazil. National Geographic Research, 1:5-20.

Barberena, M.C.; Araújo, D.C.; Lavina, E.L. \& Azevedo, S.K. 1985b. O estado atual do conhecimento sobre os tetrápodes permianos e triássicos do Brasil meridional. In: MME-DNPM: Coletânea de Trabalhos Paleontológicos (Geologia), 27(2):21-28.

Barberena, M.C. \& Dias, E.V. 1998. On the presence of a short-snouted rhinesuchoid amphibian in the Rio do Rasto Formation (Late Permian of Paraná Basin, Brazil). Anais da Academia Brasileira de Ciências, 70:465-468.

Boonstra, L.D. 1932. Pareiasaurian studies. Part IX.-The cranial osteology. Annals of the South African Museum, 31:1-37.

Broom, R. \& Robinson, J.T. 1948. Two new cotylosaurian reptiles. Annals of the Transvaal Museum, 21:51-54.

deBraga, M. 2003. The postcranial skeleton, phylogenetic position, and probable lifestyle of the Early Triassic reptile Procolophon trigoniceps. Canadian Journal of Earth Sciences, 40:527-556.

deBraga, M. \& Rieppel, O. 1997. Reptile phylogeny and the interrelationships of turtles. Zoological Journal of the Linnean Society, 120:281-354.

Dias, E.V. \& Barberena, M.C. 2001. A temnospondyl amphibian from the Rio do Rasto Formation, Upper Permian of Southern Brazil. Anais da Academia Brasileira de Ciências, 73:135-143.

Dias, E.V. \& Schultz, C.L. 2003. The first paleozoic temnospondyl postcranial skeleton from South America. Revista Brasileira de Paleontologia, 6:29-42.

Edmund, A.G. 1960. Tooth replacement phenomena in the lower vertebrates. The Royal Ontario Museum, Life Sciences Division, Contribution 52, 190 p.

Edmund, A.G. 1969. Dentition. In: Gans, C. (ed.) Biologia of the Reptilia. Volume 1. Morphology A. Academic Press, p.117-200.

Gao, K. 1983. A new pareiasaur from Liulin, Shanxi. Vertebrata Palasiatica, 21:193-203 [in Chinese, with English summary].

Golubev, V.K. 2000. The faunal assemblages of Permian terrestrial vertebrates from Eastern Europe. Paleontological Journal, 34 (supp. 2):211-224.

Gradstein, F.M \& Ogg, J.G. 2004. Geologic Time Scale 2004 Why, how, and where next!, available in http://www.stratigraphy. org/report04.pdf

Gregory, W.K. 1946. Pareiasaurs versus placodonts as near ancestors to turtles. Bulletin of the American Museum of Natural History, 86:276-323.

Hartmann-Weinberg, A. 1937. Pareiasauriden als leitfossilien. Problemy Paleontologii, 2-3:649-712.

Haughton, S.H. \& Boonstra, L.D. 1929. Pareiasaurian studies. Part I. An attempt at a classification of the pareiasaurid based on skull features. Annals of the South African Museum, 28:79-97.

Kuhn, O. 1969. Cotylosauria. Handbuch der Paläoherpetologie Teil 6 (Encyclopedia of Paleoherpetology Part 6). Jena, Veb Gustav Fischer Verlag, 89 p.

Langer, M.C. 2000. The first record of dinocephalians in South America: Late Permian (Rio do Rasto Formation) of the Paraná Basin. Neues Jahrbuch für Geologie und Paläontologie, Abhandlungen, 215:69-95.

Laurin, M. \& Reisz, R.R. 1995. A reevaluation of early amniote phylogeny. Zoological Journal of the Linnean Society, 113:165-223.
Lee, M.S.Y. 1995. Historical burden in systematic and the interrelationships of 'Parareptiles'. Biological Review, 70:459-547.

Lee, M.S.Y. 1997a. A taxonomic revision of pareiasaurian reptiles: implications for Permian terrestrial ecology. Modern Geology, 21:231-298.

Lee, M.S.Y. 1997b. Pareiasaur phylogeny and the origin of turtles. Zoological Journal of the Linnean Society, 120:197-280.

Lee, M.S.Y.; Gow, C.E. \& Kitching, J.W. 1997. Anatomy and relationships of the pareiasaur Pareiasuchus nasicornis from the Upper Permian of Zambia. Palaeontology, 40:307-335.

Lucas, S.G. 2002. A new dicynodont from the Triassic of Brazil and the tetrapod biochronology of the Brazilian Triassic. In: A.B. Heckert and S.G.Lucas (eds.) Upper Triassic Stratigraphy and Paleontology. New Mexico Museum of Natural History and Science Bulletin, 21:131-141.

Malabarba, M.C.; Abdala, F.; Weiss, F. \& Perez, P.A. 2003. New data on the late Permian Fauna of Posto Queimado, Rio do Rasto Formation, Southern Brazil. Revista Brasileira de Paleontologia, 6:49-54.

Meyer, H. von. 1859. Sclerosaurus armatus aus dem bunten Sandstein von Rheinfelden. Paläeontogrphica, 7:35-40.

Newton, E.T. 1893. On some new reptiles from the Elgin sandstones. Philosophical Transactions of the Royal Society of London B, 184:431-503.

Owen, R. 1876. Descriptive and illustrated catalogue of the fossil Reptilia of South Africa in the collection of the British Museum. British Museum of Natural History, London, $88 \mathrm{p}$.

Richter, M. 2000. Peixes fósseis do Rio Grande do Sul. In: M. Holz \& L. F. De Ros (eds.) Paleontologia do Rio Grande do Sul. Edição CIGO/UFRGS, p. 162-175.

Richter, M. \& Langer, M.C. 1998. Fish remains from the Upper Permian Rio do Rasto Formation (Paraná Basin) of southern Brazil. Journal of African Earth Sciences, 27(1A):158-159.

Rieppel, O. \& Reisz, R.R. 1999. The origin and early evolution of turtles. Annual Review of Ecology and Systematics, 30:1-22.

Rougier, G.W.; de la Fuente, M.S. \& Arcucci, A.B. 1995. Late Triassic turtles from South America. Science, 268:855-858.

Rubidge B.S. (ed.), 1995. Biostratigraphy of the Beaufort Group (Karoo Supergroup). Pretoria, South African Committee for Stratigraphy, Biostratigraphic Series 1, 46 p.

Sander, P.M. 1999. The microstructure of reptilian tooth enamel: terminology, function and phylogeny. Münchner Geowissenschaftliche Abhandlungen, Reihe A, Geologie and Paläontologie, 38, 102 p.

Schoch, R. \& Milner, A.R. 2000. Stereospondyli. Stem-stereospondyli, Rhinesuchidae, Rhytidostea, Trematosauroidea, Capitosauroidea. Handbuch der Paläoherpetologie Teil 3B (Encyclopedia of Paleoherpetology Part 3B). Munich, Verlag Dr. Friedrich Pfeil, $203 \mathrm{p}$.

Schultz, C.L. \& Dias-da-Silva, S. 1999. A possible new pareiasaurid in the Sanga do Cabral Formation, Lower Triassic (?) of Southern Brazil. Paleontologia em Destaque, 26:49.

Sidor, C.A.; Blackburn, D.C. \& Gado, B. 2003. The vertebrate fauna of the Upper Permian of Niger-II, preliminary description of a new pareiasaur. Palaeontologia africana 39:45-52.

Small, B.J. 1997. A new procolophonid from the Upper Triassic of Texas, with a description of tooth replacement and implantation. Journal of Vertebrate Paleontology, 17:674-678. 
Smith, R.M.H. \& Keyser, A. 1995a. Biostratigraphy of the Tapinocephalus Assemblage Zone. In: B. Rubidge (ed.) Biostratigraphy of the Beaufort Group (Karoo Supergroup). Pretoria, South African Committee for Stratigraphy, Biostratigraphic Series 1, p. 8-12.

Smith, R.M.H. \& Keyser, A. 1995b. Biostratigraphy of the Pristerognathus Assemblage Zone. In: B. Rubidge (ed.) Biostratigraphy of the Beaufort Group (Karoo Supergroup). Pretoria, South African Committee for Stratigraphy, Biostratigraphic Series 1, p. 13-17.

Smith, R.M.H. \& Keyser, A. 1995c. Biostratigraphy of the Tropidostoma Assemblage Zone. In: B. Rubidge (ed.) Biostratigraphy of the Beaufort Group (Karoo Supergroup). Pretoria, South African
Committee for Stratigraphy, Biostratigraphic Series 1, p. $18-22$.

Smith, R.M.H. \& Keyser, A. 1995d. Biostratigraphy of the Cistecephalus Assemblage Zone. In: B. Rubidge (ed.) Biostratigraphy of the Beaufort Group (Karoo Supergroup). Pretoria, South African Committee for Stratigraphy, Biostratigraphic Series 1, p. 23-28.

Sues, H.-D.; Olsen, P.E.; Scott, D.M. \& Spencer, P.S. 2000. Cranial osteology of Hypsognathus fenneri, a latest Triassic procolophonid reptile from the Newark Supergroup of eastern North America. Journal of Vertebrate Paleontology, 20:275-284

Received September, 2004; accepted February, 2005. 